\title{
Distinguishing Mediality: The Problem of Identifying Forms and Features of Digital Comics
}

\author{
LUKAS R.A. WILDE, Eberhard-Karls University of Tuebingen
}

\begin{abstract}
Do digital comics constitute a different "medium" than print comics? Many researchers have discussed whether comics make up a medium at all. The problem seems to be, in contrast to films or video games, the absence of a defining technology. Whatever separates a given "medium" in a conventional sense from others, however, doesn't actually lie in its technological, material or semiotic properties, but in its culturally qualifying aspects: recognizable medial forms, for instance, that distinguish a medial configuration sufficiently for given observers. This article understands the mediality of (digital) comics as partly produced by rhetorical effects, based on contested discussions and discourses surrounding the alleged differences and similarities between digital and print comics. It aims to show how we can not only observe digital comics as new objects of inquiry, but actually observe said distinctions in order to learn something about the changing cultural implications of "comicness" in general, as well as about the interplay between material and technological properties on the one hand and compositional aspects on the other.
\end{abstract}

\section{KEYWORDS}

Digital comics, digitalization, materiality, mediality, multimodality. 


\section{Introduction}

The distinction between analog and digital has been considered the last century's most fundamental differentiating feature in media history (Schröter 2004, 8; Paech \& Schröter 2008). With reference to comics, "digitalization" can point towards at least three different phenomena:

1. Webcomics, produced originally for and enjoyed primarily online via websites, blogs or social media (cf. Kukkonen 2014);

2. eComics which - regardless of their origin - are delivered and received by platforms such as ComiXology and by reading technologies like Guided View (cf. Wershler 2011; Hague 2014, 111);

3. The digitalization and archiving of existing comic books, as in the cases of scans or scanlations (cf. Wright 2008; Douglass, Huber \& Manovich 2011; Wershler, Siervo \& Tien 2014). ${ }^{1}$

In spite of such a variety of practices, comics have been considered 'the medium most resilient to digitalization' (Gardner 2014, 207). In fact, despite Ian Hague's observation that 'materiality as a whole remains a relatively neglected area of comics scholarship' (Hague 2014, 23), a great many studies in recent years have focused on the very 'material richness' (Kashtan 2013a; cf. Priego Ramirez 2011; Jenkins 2013) of print comics, precisely as a defining feature. While such debates might be easily dismissed as turf wars between older and newer generations, ${ }^{2}$ different assessments of comic books" "mediality" in relation to analog or digital delivering technologies nevertheless point to a theoretical conundrum very specific to comics and comics theory; their notorious hybrid state between a "genre" on the one hand and a "medium" on the other (cf. Rippl \& Etter 2013; Mitchell 2014). While this disputed doublenature has become a kind of cliché itself, the question keeps coming back as to where generic conventions and medial "specifics" diverge.

Comics are considered 'conventionally-distinct media' within a larger 'media convergence culture' (cf. Jenkins 2006a; 2006b; Gardner 2012) and are compared and contrasted to other narrative media like film or videogames. Whenever other media try to emulate or "remediate" a specific comic book "look" by references to comic book aesthetics (think of Sin City or Scott Pilgrim, cf. Bolter \& Grusin 2000; Thoss 2014), an established medial identity of comics is taken for granted. Understanding forms of media purely as technological arrangements or technical systems betrays a vast underestimation of their symbolic, semiotic and cultural side (cf. Ryan 2005, 15; Herzogenrath 2012). Where then does a "digital comic" fall in terms of these aspects? Does the comic, as one such "medium", simply travel into another technological distribution context, as McCloud and many others seem to think (cf. McCloud 2000)? Or should we rather speak of a "new medium", closer to animation or browser games where movement, sound or interactive features are involved (cf. Goodbrey 2013b)? This article aims to offer tentative answers to the question of how the mediality of digital comics might be understood.

In a first step, the relation between a "conventionally distinct medium" - as a cultural given and the dynamic processes shaping, modifying and transforming the conventions of this distinct medium has to be illuminated. Against a backdrop of competing models of

\footnotetext{
${ }^{1}$ For an extensive discussion on the usefulness of such a distinction see Hammel (2014, 20-26).

${ }^{2}$ Best observed in the notorious public debate between Scott McCloud and Fantagraphics co-owner Gary Groth, already considered 'part of the contemporary history of the medium' (Duncan \& Smith 2013, 496; cf. Cave 2001).
} 
(inter)mediality by Irina O. Rajewsky, Lars Elleström, and Julian Schröter, we will then address three major sites of (alleged) differentiation between analog and digital comics. Firstly we will consider a distinction of formal aspects, focusing on different ways to conceptualize new modes or features (like movement or sound) in terms of digital or analog mediality. The second formal aspect will address the Infinite Canvas and it's "opposite", the breakdown of narrative units through distribution on several physical pages. Both techniques have been addressed as specific for the respective "medialites" of digital and print; this article will point out the flexibility of both arguments to be turned around, depending on the observer's respective presuppositions. Finally, we will address the influence of neighboring media (literature, film or fine art vs. websites and blogs) as points of comparisons. The aim is not to present an exhaustive survey on the complicated and disputed discussions about the mediality of comics (cf. Wilde 2014), but rather to indicate how this mediality can and should be understood also as a (changing) cultural conceptualization of what to expect of "comicness".

\section{Modes and medium-specific features}

Within the quickly expanding scholarly field surrounding the buzzword "intermediality", two heterogeneous directions have established themselves that rarely take note of each other, as Rajewsky conceded in 2008 (48). On the one hand concepts and approaches continue to be derived from literary theory and art history, while on the other hand from media theory in a broader sense. Within the former, in the tradition of interart studies and Julia Kristeva's concept of 'intertextuality' (1984), borders between conventionally distinct forms of art and media are taken as a given. ${ }^{3}$ As a "site" of inquiry, we therefore have to address the singular text or work of art, with "intermediality" constituting one of its employed strategies. Within the broader approach (coined under the term 'media theory' by Rajewsky $(2008,49)$ ), not any single object is of interest, but rather the forces shaping our conventional understanding of such "media" and their conceptual borders. The object of interest, then, is "the set of prototypical properties that can be considered constitutive for a conventionally distinct medium' (Thon 2014, 334; emphasis mine - L.W.): The focus lies as much on contested discourses surrounding media practices as it does on actual media configurations. ${ }^{4}$

In other words, "mediality" can be considered to be a set of communicative distinctions, not a set of properties (cf. Paech 1998; Ernst 2012; Wilde 2014). These "constitutive properties" are doubtlessly limited, but in no way determined by their actual material, technological, institutional or semiotic bases (cf. Bouyer 2014). Those only serve as a potential for distinctions, themselves being indifferent towards their actualization. Which of them are considered constitutive (rather than merely transitory and incidental to the "medium") is up to the observer. A good starting point to connect both approaches in order to pin down the relations between digital and analog comics should be Elleström's model for intermedial relations (2010). This combines a quite complex notion of "multimodality" with a nuanced

\footnotetext{
${ }^{3}$ Rajewsky's own influential work on intermediality can be subsumed under this approach (2010), as can Werner Wolf's contributions $(1999 ; 2005)$.

${ }^{4}$ This is neither to imply a somehow "unmediated" nature of verbal or written discourse (cf. Schröter 2012, 29), nor that artistic expressions (like comics) are not part of discourse practices themselves. On the contrary, it has to be noted that one could observe these distinctions within the media configurations under discussion themselves, as references of one "medium" to another (for instance in the fashion of Jay David Bolter and Richard Grusin's notion of remediation, (cf. 2000), or as artistic media archaeology, (cf. Parikka 2012, 136). In order to be able to observe such references, we first of all need to know what the represented medium (allegedly) is, as well as what the representing medium (allegedly) is (cf. Schröter 2012, 27). This approach will have to be taken another time (cf. Wilde 2014; for webcomics see also Kirchoff 2013; Jacobs 2014, 8;).
} 
understanding of culturally "qualifying aspects". At first sight, a notion of multimodality seems crucial to understand comics' specifics. In the theoretical framework developed from social semiotics, a "mode" is understood as a semiotic resource: "signifiers [...] that have been drawn into the domain of social communication' (van Leeuwen 2005, 4; cf. Kress 2010). To consider such modes seems essential, not only because of the alleged image/text 'intersemioticity' of comics (Groensteen 2014, 105) that has often been described as a multimodality between iconic and symbolic signs (cf. Rippl \& Etter 2013, 193), but also because of changes in webcomics modal resources. It might prove insightful to adopt Elleström's meticulous model of modalities for comics. ${ }^{5}$ However, that lies outside the scope of this article. The identification of modes is at best vaguely connected to the identification of "media" in a cultural sense. In Elleström's words, this 'can be determined only by way of investigating historically determined practices, discourses and conventions' (2010, 25). Obvious examples for that can be found in other artistic practices, as Elleström argues: 'In order to be counted as a painting instead of only paint spread around, however, the picture must be produced and presented within generally accepted social and artistic frames' (26). In the same way, cinema did not become "cinema" the day the technology (to process the mode of the moving image, say) was invented. Elleström points out that although 'the first films also had distinct communicative and aesthetic characteristics... ... it took a while before the many qualifying characteristics of the mediated content developed into recognizable media forms' (25). Such recognizable forms can be comprised of Elleström's "qualifying aspects". Whatever those are, he leaves deliberately open by stating:

I refrain from trying to say exactly what "aesthetic and communicative characteristics" are. Actually, any understanding of these characteristics is part of the way the operational qualifying aspects work - all changes in aesthetic conceptions, and even a denial of the point of thinking in terms of aesthetics, take part of the forming of qualified media (44).

As right as that may be, the characteristics will not all be arbitrary in a given historical context. Schröter's conception of 'arch-intermediality' (2012) is quite helpful here. If we follow his argument, the features most relevant to define a medium will always be those which serve as the best distinction from - or comparison with - other media. Paradoxically then, this conception of intermediality precedes already defined media. Schröter gives a good example by pointing out that:

if we want to find a definition for photography, for instance - if we want to name those elements that are specific to it - then first of all that specific point would have to be identified for which this definition supposedly applies. It would be insufficient to determine that photography creates square pictures. [...] Thus, if they are contrasted with painting then photography is a medium which creates indexical pictures (Schröter 2012, 29; orig. emphasis).

Since this criterion in Schröter's example would clearly not suffice to differentiate photography from film, we would need to find another aspect that differentiates those two "media". We could for instance then use the forms of movement vs. stasis, but this would not be enough to specify what differentiates photography from the "medium of polaroid". As Schröter observes, we "can see from this that whatever seems to be specific in a given medium

\footnotetext{
${ }^{5}$ Under the header "modality", Elleström comprises four different aspects of communicative situations, "basic categories of features, qualities and aspects of media' $(2010,15)$, ranging from the material to the sensorial to the conceptual.
} 
depends on "what the others are not"" (ibd.). These recognizable media forms - differences that make a difference to an observer ${ }^{6}$ - are exactly what are usually discussed by intermediality studies in the tradition of Rajewsky and Wolf. Intermedial references depend on the evocation (and therefore identification) of formal techniques and recognizable features of other media - whatever may count as such. In many cases such features do not depend on technology at all. In her insightful reading of Bill Willingham and Mark Buckingham's Fables 7: Arabian Nights (and Days) (2006) as an intermedial renegotiation, Karin Kukkonen for instance argues that:

Other media for example refer to comics by emulating how modes are used in that medium, such as using split-screens in film to reproduce panels on the page, or inserting speech bubbles in printed books that do not otherwise exploit the visual mode $(2011,41)$.

It is crucial to note that Kukkonen's use of 'medium-specific mode' is nowhere near Elleström's tightly defined set of analytical features. In fact, it actually refers more to qualifying factors such as historically contingent, discursively produced forms and features of conceptual "comicness". To define comics we are utterly reliant on such aesthetical and compositional characteristics, up to the point where even such a highly conventional device as the speech bubble is used as a criterion (cf. Carrier 2000; Balzer \& Wiesing 2010). The historiography of comics can be read as a dual attempt of two pursuits. On the one hand the aim is to exclude whatever doesn't conform to given qualifying aspects (cartoons, picture books, caricature and so on). On the other hand the aim is to include whatever should "actually" be considered comics, although differently named at the time (medieval drawings, copper engravings, all the way to cave paintings) (cf. Hague 2014, 11; Groensteen 2014). Mostly those features rely on semiotic aspects alone. Only sometimes are technological and institutional properties taken as relevant. A good example of this is Sean Carney's statement that 'what makes a comic book a comic book is that it has the appearance of something handmade' (Carney 2008, 195; cf. Packard 2009, 113; Gardner 2011). Similarly, David Kunzle insists that comics are (or are at least printed within) a mass medium (Kunzle 1973, 2; cf. Sabin 2006, 11). In summation, to study the mediality of digital comics it might be more useful to take a discourse analysis approach and observe the "differences that make a difference", instead of producing new ones ourselves. These include the rhetorical effects of qualifying features and differentiating forms marked by other observers, their dependence on other media as points of comparison or distinction, and their actualization (or ignorance) of technical, institutional, cultural and semiotic potentials.

\section{Forms and qualifying features of digital comics}

With relation to the realm of the digital, the forms and features of comics are shifting in interesting ways. The most obvious example for a distinction not called for within print culture would be to define a difference from animation. Confronted with experimental webcomics and motion comics this is a pressing task for theorists and practitioners alike. Film and media scholar Scott Bukatman observed that the McCloud/Groth debate (see footnote 2) was centered precisely on 'the proper "place" of movement' $(2011,137)$ and on an alleged "pollution" of the conceptual purity of comics by this foreign matter. Less to argue for an essentialist approach, but rather for clarity of definition, comics scholar Jakob F. Dittmar also

\footnotetext{
${ }^{6}$ For a more detailed discussion of this Niklas Luhmann and George Spencer-Brownian approach to comics' mediality cf. Wilde 2014.
} 
notes: 'If these stories contain film and/or audio elements, they are no longer comics in accordance with the established definition of this class of media'(2012, 88; emphasis mine L.W.). This establishment, however, is exactly what is at stake here. If movement and sound are clearly different "modes" - in terms of their spatiotemporal and sensorial reception, as well as in terms of semiotics - how could they be treated as comics? Since sound and movement are both time-based phenomena, they seem to contradict comics' conception of space as representation of time - the 'conceptual fundament of the medium' (Bukatman 2011, 134). ${ }^{7}$ Daniel Merlin Goodbrey pursues this question with references to practitioners such as director Guilermo del Toro, webcomic artists Demian Vogler (Demian.5) and John Barber or cartoonist Yves Bigerel, who all seem to agree that 'Comics are Control' (2013a, 194). Barber argues that: 'In reading, the reader controls the rate at which information is absorbed. This is inherent in comics; this is what separates comics from film' (cf. ibid., 195; Barber 2002). If, however, not movement per se seems to be the crucial issue, but the control over movement, even highly animated webcomics like Stevan Živadinović's Hobo Lobo of Hamelin (2011) could still be placed within comics' mediality. After all, the reader is still able to scroll the animations back and forth 'according to individual pacing and interests' (Dittmar 2012, 89). The control over movement 'repositions the moving image as a syntagm within a larger signifying structure', Bukatman concedes $(2011,142)$, therefore differing greatly from the real-time immersion of cinema or videogames. With an even more refined eye for conceptual distinctions, Goodbrey even points at a "printed-page working precedent" for autonomously looping animations as can be found in Vogler's When I Am King (2001) and Patrick Farley's First Word (2012). He notes that:

A simple example... [in print] ...might be a dog chasing its own tail. The reader sees within a single panel the same dog in multiple positions as it rotates in place (Goodbrey 2013a, 194).

Such 'polymorphic panels', as cognitive scientist Neil Cohn coined them (2010, 131), do show continuous movements as conceptual units - to Goodbrey as an observer, animated Gifs are therefore just an updated version of that same old principle. It is not the "modality" as such that serves as a qualifying aspect for the inclusion or exclusion of/from media boundaries, but the conception of the modality as exemplifying media-specific forms.

In the case of both Reader Control and Polymorphy, newly found (or marked) features and forms work to sharpen our understanding of "normal" comics. They also serve to render analog and digital techniques as variations of the same, more abstract principle within the same mediality. In other cases this rhetoric is turned around. The form (of analog/digitaldifferentiation) most often used would be McCloud's Infinite Canvas. Dittmar argues that the 'lack of any printed page leads to an end of conventional narrations and dramaturgical necessities,' (2012, 84). The countless uses of the 'unbroken reading line' (McCloud 2000, 218) as a conceptual principle has been the object of many studies since, marking it as webcomics' pivotal aesthetic feature. Apparently, it seems only feasible in the realm of the digital. However, if we take a look back at the term's origins in Reinventing Comics, nothing could be further from McCloud's intentions than to mark a watershed to "actual" comic tradition. The opposite is the case, as Bukatman saw clearly:

Citing the precedents of walls of hieroglyphs, the Bayeux Tapestry, Trajan's Column and the Codex Nutall... [McCloud] ...notes that each produced an "unbroken reading

\footnotetext{
${ }^{7}$ A concept ironically promoted by McCloud himself and his idea of comics as a 'temporal map' $(1994,67 ; 91)$, the 'essence of comics' $(2000,206)$.
} 
line" that exists in contradistinction to the later experience of reading that followed from print culture's segmentation of information onto separate pages $(2011,139)$.

Although McCloud's understanding has been criticized (cf. ibid.), what is of relevance here is the respective notion of technologically caused alterations. In McCloud's reading, print is the technology that interrupted a tradition, rather than the other way round. ${ }^{8}$ To him the principle of the unbroken line is made accessible again by online comics. Referring to the more elaborated theoretical concepts of Thierry Groensteen, Dale Jacobs examines the expanding "panel-map" of Randall Munroe's xkcd: Click and Drag (2012). He points out that this webcomic can be understood as a new domain of comics' founding principle, arthrology, and that the linkages between images distributed over the work as a whole can:

in this case can be seen to refer to different panels created in the act of clicking and dragging. That is, the reader must hold these disparate panels in mind and make connections between them when attempting to make meaning from the strip as a whole' (Jacobs 2014, 11; cf. Groensteen 2007, 144).

This flexibility to be exploited as a qualifying factor for both sides for the analog/digitaldivide is equally provided by the Infinite Canvas" "opposite": the breakdown of narrative units through distribution on several physical pages. The interruption of the continuous flow of reading and the necessity to turn a page can be understood as a technical condition brought on by print or it can be conceptualized as a design principle, which is especially salient in digital comics. Goodbrey observes the concept of the page turn in the digital compositional principle of Panel Delivery, i.e. the grouping of panels to narrative and rhythmic units, separated and connected by hyperlinks (as in the "interactive comic documentaries" of Cartoon Movement: 'Chicago is My Kind of Town' by Luke Radl, 2012, or 'The International Criminal Court' by Dan Archer, 2013). This principle builds on traditional 'compositional tricks and tropes established by print' (Goodbrey 2013a, 190), such as the micro-cliffhanger at the bottom of a page. Within the digital, the technique gains higher flexibility, allowing creators to set their own (sometimes surprising) pace throughout the narrative. Goodbrey elaborates that in 'a traditional comic the pace of advancement through the story is fixed to the repetitive beat of the page turn. In contrast, advancement through a digital comic does not have to be tied to the same rhythm' (ibid.,191). Reevaluations of the Infinite Canvas and Panel Delivery highlight how used we ar to print and the physical conditions it imposes. So much so that scholars no longer consider it as a technology and possible distinguishing part of comics' mediality. One of digital comics' potentials might lie in this very chance 'to think comic theory differently', as media theorist Ramòn Reichert put it (2011, 138). Mediality and materiality are not then, as Christian J. Emden and Gabriele Rippl would have it, 'two sides of the same coin' $(2010,8) .{ }^{9}$ Rather, materiality can always become crucial to the mediality of comics, mostly as a dormant potential, offering to be marked as a resource for meaningful differences (for instance by changes of the physical format of publications, (cf. Couch 2000;

\footnotetext{
${ }^{8}$ This argument resembles the notion of a "Secondary Orality" on the internet. To Walter J. Ong, for instance, knowledge is increasingly shaped by a new kind of "post-literacy orality", marking the previous 500 years a mere 'Gutenberg Parenthesis' (cf. Ong 1982).

${ }^{9}$ It should be emphasized that "materiality" could serve as a fruitful concept for the study of digital comics as well. Reichert, informed by German media theorist Friedrich A. Kittler, stresses the point that digital content also rests on a material foundation; the scripts, program codes and network structures (2011, 135; cf. Hammel 2014, 58). Those 'materialities of technologies' (Parikka 2012, 164; cf. Kittler 1999; Winthrop-Young 2011) can also be addressed as conceptual forms within more self-reflective or interactive webcomics such as Hannes Niepold and Hans Wastlhuber's The Church of Cointel (2000-), or XKCD's performative episodes Lorenz (2014a) and Pixels (2014b).
} 
Lefèvre 2000)). Until recently that has seldom occurred, as Hague observed. The huge increase of studies on comic books' physical and corporeal properties in recent years is doubtlessly informed by digital comics' enormous increase in popularity as a new point of comparison and distinction.

\section{New comparisons, new differences}

The relation of a "specific" comic book mediality to other forms of media or cultural practices can be observed in the digital/print divide on the "micro-level" of mostly semiotic qualifying forms. However, it can also be seen in the interplay with neighboring media, and so we turn our attention from distinctions to comparisons. It is well known that early cinema for instance, was understood in terms borrowed from elsewhere, such as 'recorded theatre' or 'visual literature' (cf. Elleström 2010, 25; Scheid 2005). This, however, is not something which can or should be avoided for a "purer" definition at some point; on the contrary:

The terms for the description of a new medium can only be borrowed from the already existing language and be composed from existing terms into neologisms. And so the recourse to metaphors referring to other media, such as "visual music", "writing of light" cannot be avoided (Schröter 2012, 29).

The same is true for comics. The discussion of comics has long drawn on comparisons to both literature and the fine arts; it is either the literary complexity of the novel or the aesthetic quality of the painting that serves as a point of comparison to other art forms (cf. Baetens 2012). ${ }^{10}$ This is precisely how we arrive at comics' definition as either "graphic novel" or "sequential art" and all the aesthetical aspects (and criteria of quality) associated with them. Such metaphorical transfers highlight or suppress recognizable forms and features derived from their domains of origins (cf. Scheid 2005, 22; Kirchmann/Ruchatz 2014, 24). Within a changing context of production and reception in the realm of the digital, new points of comparisons - and thus new metaphors - appear. It is quite insightful that the German Webcomic award Lebensfenster, which is presented annually since 2011, is not called "webcomic award" at all, but rather "Award for Graphic Blogging". Blogging as the media form or practice of comparison activates completely different associations (cf. Bolter 2001; Heibach 2003; Page 2014). These usually don't highlight semiotic dimensions of mediality, but rather institutional and cultural ones, resulting in studies that focus on the communicative and interactional functions of online comics (cf. Hicks 2009; Banhold/Freis 2012, 174). Again it becomes possible for scholars to conceptualize comics as a whole, both analog and digital, by these new criteria. In Fenty, Houp and Taylor's retroactive understanding of 1960s and 70s underground comix practices (2004), online platforms are compared to Xerox copying machines (in terms of reproduction technologies) and blogs to head shops (in terms of "illegitimate" distribution channels). ${ }^{11}$

The most interesting differentiation between analog and digital comics might then not lie in new features that were made possible 'through the affordances of the new medium' (Jacobs 2014, 9). Instead, differentiation may come from self-imposed limitations derived from new

\footnotetext{
${ }^{10}$ Where narrative strategies and formal conventions are under discussion, the proximity to film and cinema is mentioned frequently as well; both are considered in terms of culture and content (for a historical discussion cf. Gardner 2012; Ahrens 2012; Sina 2014), as well as of formal characteristics (close ups, establishing shots etc., cf. Christiansen 2000; Levèfre 2012).

${ }^{11}$ Critical remarks on the biases and discrepancies of this comparison have been expressed (cf. Banhold \& Freis 2012, 166).
} 
points of comparisons, which rely less on semiotic or material dimensions. If we look at established qualifying factors of comics again, "picture-sequentiality" has been crucial to both McCloud $(1994,7)$ and Will Eisner $(1985,5)$, yet many webcomics today don't seem to conform to that. Mathew Inman's The Oatmeal (2009-) was awarded with the Eisner Award for "Best Digital Comic" on July $25^{\text {th }} 2014$. However, it not only features single images quite prominently, but the series also frequently dispenses with "pictures" altogether in order to employ humorous diagrams, infographics or charts. This didn't seem to bar the jury from considering Inman for the "comic" award, correlating to a general tendency of what can (still) be considered a webcomic. Randall Munroe's XKCD (2005-) or Will Samari, Ray Yamartino and Rafaan Anvari's Doghouse Diaries (2009-) are two of the most popular webcomics today, and both employ single images, humorous diagrams, charts and infographics. All three series are frequently mentioned in "favorite webcomic" lists, despite their restricted formal features. Such popular domains of discourse must be taken seriously. Diagrammatic gags in or even as - webcomics feature highly recognizable aesthetics that have developed almost into a sub-genre by now (cf. Wilde 2012). Although it is futile to speculate whether The Oatmeal, Doghouse Diaries or XKCD could have emerged within a print culture alone, one can certainly point to a shift in reference to other other media here. Their environments blogs, social media or message boards - will continue to exercise significant influence on what will be seen as comics' recognizable features and functions in the future. Sometimes these neighbouring forms of communication seem so closely integrated with each other that it is open for debate whether a weblog can, should or even aims to be counted as "a webcomic" (with some "paratexts" attending) or as a "regular" blog with some recurring illustrations.

If there is an "actual" feature common to all kinds of digital comics, it might be their higher degree of flexibility to choose their own forms and limitations. ${ }^{12}$ As Bukatman states: 'When I visit a website it is not clear exactly, what kind of text/image/motion nexus I will be encountering' (2011, 136; cf. Dittmar 2012, 87). In the area of digital aesthetics, the specificity of any "medium" might not be bound to material limitations anymore (cf. Schröter 2008, 588; Murray 2012, 23), its mediality becoming 'more "fluid," more tentative, only valid until the next technological or institutional landslide' (Thon 2014, 336). While such developments are of great importance, I hope to have at least hinted at the relevance of discursive shifts and dynamics as well. Our understanding of mediality is then equally informed by rhetorical effects that continue to shape our conceptual media borders, both in scholarly discourses and in popular ones. If for comics 'digital technology and the internet have been game-changers' as Groensteen noted (2014, 99), the discussions of what is considered prototypical to print comics, to digital comics - and to comics' relation between technology and compositional features in general - will only become more contested in the future. Or, as McCloud put it programmatically: 'As the technological distinctions between media fall away, their conceptual distinctions will become more important than ever' (2000, 205). For media scholars it might be more insightful to observe and study such contests, rather than participate in them. ${ }^{13}$

\footnotetext{
${ }^{12}$ If we turn our attention away from the more experimental webcomics to commercially successful e-comics the fastest growing market of American and Japanese comics right now - there is an opposite tendency. Hammel notes that, due to an orientation towards tablets and smartphones, a growing homogenization in formats can be observed. For instance, most panels tend to conform to display related sizes (cf. 2014, 76).

${ }^{13}$ This article owes much to the many valuable suggestions of Cord-Christian Casper from the ChristianAlbrechts University of Kiel and the editing board of the Closure journal. For linguistic assistance I would like to thank Lucas Ogden from the University of Tübingen.
} 


\section{References}

Ahrens, J. (2012) 'Intermedialität, Hybridität: Wieviel Unbestimmtheit verträgt der Comic?', in C. Bachmann (ed), Comics intermedial: Beiträge zu einem interdisziplinären Forschungsfeld, Essen: Christian A. Bachmann Verlag, pp. 11-22

Archer, D. (2013) 'The International Criminal Court', Cartoon Movement [online]. Available at http://www.cartoonmovement.com/icomic/32. Accessed 18 April 2015.

Baetens, J. (2012) 'Words and Images in the Contemporary American Graphic Novel', in B. Herzogenrath (ed), Travels in Intermedia[lity]: ReBlurring the Boundaries, Hanover: University of New England Press, pp. 92-110

Balzer, J. and Wiesing, L. (2010) Outcault: Die Erfindung des Comic, Bochum and Essen: Christian A. Bachmann Verlag

Banhold, L. and Freis, D. (2012) 'Von postmodernen Katzen, abwesenden Katzen und Dinosaurier reitenden Banditen: Medienästhetik, Distribution und medialer Kontext von Webcomics', in C. A. Bachmann, V. Sina and L. Banhold (eds), Comics intermedia: Beiträge zu einem interdisziplinären Forschungsfeld, Essen: Christian A. Bachmann Verlag, pp. 159-179

Barber, J. (2002) The Phenomenon of Multiple Dialectics in Comics Layout, Master's thesis, London: London College of Printing

Bolter, J. (2001) Writing Space: Computers, Hypertext, and the Remediation of Print, Mahwah: Lawrence Erlbaum Associates

Bolter, J. and Grusin, R. (2000) Remediation: Understanding New Media, Cambridge: MIT Press

Bouyer, S. (2014) 'There is no Specificity at the Number You have Dialed (1986)', in A. Miller and B. Beaty (eds), The French Comics Theory Reader, Leuven: Leuven University Press, pp. 75-82

Bukatman, S. (2011) 'Online Comics and the Reframing of the Moving Image', in D. Harries (ed), The New Media Book, London: BFI Publishing, pp. 133-143

Carney, S. (2008) 'The Ear of the Eye, or, do Drawings Make Sounds?', English Language Notes, 46, 193-209

Carrier, D. (2000) The Aesthetics of Comics, University Park: Pennsylvania State University Press

Cave, D. (2001) 'No Laughing Matter. BANG! POW! ZAP! Online Comics Come under Assault from the Art Form's Old Guard', Salon.com [online]. Available at http://www.salon.com/2001/08/09/comics_2/. Accessed 18 April 2015.

Christiansen, H. (2000) 'Comics and Film: A Narrative Perspective', in H. Christiansen and A. Magnusson (eds), Comics \& Culture: Analytical and Theoretical Approaches to Comics, Copenhagen: Museum Tusculanum Press and University of Copenhagen, pp. 107-121

Cohn, N. (2010) 'The Limits of Time and Transitions: Challenges to Theories of Sequential Image Comprehension', Studies in Comics, (1)1, 127-147

Couch, Chris (2009) 'The Publication Formats of Comics, Graphic Novels and Tankobon', Image [\&] Narrative, (1)1 [online]. Available at http://www.imageandnarrative.be/inarchive/narratology/chriscouch.htm. Accessed 18 April 2015.

Dittmar, J. (2012) 'Digital Comics', Scandinavian Journal of Comic Art, 1.2 [online]. Available at http://sjoca.com/wp-content/uploads/2013/01/SJoCA-1-2-ForumDittmar.pdf/. Accessed 18 April 2015.

Douglass, J., Huber, W. and Manovich, L. (2011) 'Understanding Scanlation: How to Read One Million Fan-Translated Manga Pages', Image [\&] Narrative, (12)1 [online]. Available at 
http://www.imageandnarrative.be/index.php/imagenarrative/article/viewFile/133/104. Accessed 18 April 2015.

Duncan, R. and Smith, M. (2013) Icons of the American Comic Book [2 volumes]: From Captain America to Wonder Woman, Santa Barbara: Greenwood

Eisner, Will (1985) Comics and Sequential Art, Tamarac: Poorhouse Press

Elleström, L. (2010) 'The Modalities of Media: A Model for Understanding Intermedial Relations', in L. Elleström (ed), Media Borders, Multimodality and Intermediality, Basingstoke: Palgrave Macmillan, pp. 11-50

Emden, C. J. and Rippl, G. (2010) 'Introduction: Image, Text and Simulation', in C. Emden and G. Rippl (eds), ImageScapes. Studies in Intermediality. Oxford: Lang, pp.1-18

Ernst, C. (2012) 'Von der Schrift zum Bild: Postkonstruktivistische Motive in der Diskussion um Medialität', in C. Ernst, P. Isenböck and J. Renn (eds), Konstruktion und Geltung. Beiträge zu einer postkonstruktivistischen Sozial- und Medientheorie, Wiesbaden: Springer VS, pp. 205-232

Farley, P. (2012) 'The First Word', Electric Sheep Comix [online]. Available at http://www.electricsheepcomix.com/delta/firstword/. Accessed 18 April 2015.

Fenty, S., Houp, T. and Taylor, L. (2004) 'Webcomics: The Influence and Continuation of the Comix Revolution', ImageTexT: Interdisciplinary Comics Studies, (1)2 [online]. Available at http://www.english.ufl.edu/imagetext/archives/v1_2/group/. Accessed 18 April 2015

Gardner, J. (2011) 'Storylines', SubStance, (40)124, 52-69

Gardner, J. (2012) Projections: Comics and the History of Twenty-First Century Storytelling, Stanford: Stanford University Press.

Gardner, J. (2014) 'Film + Comics: A Multimodal Romance in the Age of Transmedial Convergence', in M. Ryan and J. Thon (eds), Storyworlds across Media: Towards a Media-Conscious Narratology, Lincoln and London: University of Nebraska Press, pp. 193-210

Goodbrey, D. (2013a): 'Digital Comics - New Tools and Tropes', Studies in Comics, (4)1, 185-198

Goodbrey, D. (2013b): 'From Comic to Hypercomic', in: J. Evans and T. Giddens (eds), Cultural Excavation and Formal Expression in the Graphic Novel, Oxford: Interdisciplinary Press, pp. 291-302

Groensteen, T. (2007) The System of Comics, Jackson: University of Mississippi Press

Groensteen, T. (2014) 'Definitions (2012)', in A. Miller and B. Beaty (eds), The French Comics Theory Reader, Leuven: Leuven University Press, pp. 93-114

Hague, I. (2014) Comics and the Senses: A Multisensory Approach to Comics and Graphic Novels, London: Routledge.

Hammel, B. (2014) Webcomics: Einführung und Typologie, Berlin: Christian A. Bachmann Verlag

Heibach, C. (2003) Literatur im elektronischen Raum, Frankfurt a.M.: Suhrkamp

Hicks, M. (2009) “"TehFutar": The Power of the Webcomic and the Potential of Web 2.0', in R. Scully and M. Quartly (eds), Drawing the Line: Using Cartoons as Historical Evidence, Monash University ePress, n.pag. [online]. Available at http://books.publishing.monash.edu/apps/bookworm/view/Drawing+the+Line/77/xhtm 1/chapter11.html. Accessed 18 April 2015.

Herzogenrath, B. (2012) Travels in Intermedia[lity]: Reblurring the Boundaries, Hanover: University of New England Press

Inman, M. (2009-) The Oatmeal [online]. Available at http://www.theoatmeal.com. Accessed 18 April 2015. 
Jacobs, D. (2014) 'Webcomics, Multimodality, and Information Literacy', ImageTexT: Interdisciplinary Comics Studies, (7)3 [online]. Available at http://www.english.ufl.edu/imagetext/archives/v7_3/jacobs. Accessed 18 April 2015.

Jenkins, H. (2006a) Convergence Culture: Where Old and New Media Collide, New York: New York University Press

Jenkins, H. (2006b) 'Comics and Convergence Part One', Confessions of an Aca-Fan: The Official Weblog of Henry Jenkins [online]. Available at http://henryjenkins.org/2006/08/comics_and_convergence.html. Accessed 18 April 2015.

Jenkins, H. (2013) 'Archival, Ephemeral, and Residual: The Functions of Early Comics in Art Spiegelman's In the Shadow of No Towers', in D. Stein and J. Thon (eds), From Comic Strips to Graphic Novels. Contributions to the Theory and History of Graphic Narrative, Berlin: De Gruyter, pp. 301-322

Kashtan, A. (2013) 'Digital Comics and Material Richness', ComicsForum [online]. Available at http://comicsforum.org/2013/07/12/digital-comics-and-material-richnessby-aaron-kashtan/. Accessed 18 April 2015

Kirchoff, J. (2013) 'It's Just Not the Same as Print (and It Shouldn't Be): Rethinking the Possibilities of Digital Comics', Technoculture: an Online Journal of Technology in Society, 3 [online]. Available at http://tcjournal.org/drupal/vol3/kirchoff. Accessed 18 April 2015.

Kittler, F. (1999) Grammophone, Film, Typewriter, Stanford: Stanford University Press

Kress, G. (2010) Multimodality: A Social Semiotic Approach to Contemporary Communication, London: Routledge

Kristeva, J. (1984) Revolution in Poetic Language, New York: Columbia University Press

Kukkonen, K. (2011) 'Comics as a Test Case for Transmedial Narratology', spec. issue of SubStance, (40)124, 34-52

Kukkonen, K. (2014) 'Web Comics', in M. Ryan and B. Robertson (eds.), John Hopkins Guide to Digital Media, Baltimore: John Hopkins University Press, pp.521-524

Kunzle, D. (1973) History of the Comic Strip Volume I, Berkeley: University of California Press

van Leeuwen, T. (2005) Introducing Social Semiotics, London: Routledge

Lefèvre, P. (2000) 'The Importance of being "Published". A Comparative Study of Different Comic Formats', in A. Magnussen and H. Christiansen (eds), Comics and Culture: Analytical and Theoretical Approaches to Reading Comics, Copenhagen: Museum Tusculanum Press and University of Copenhagen, pp. 91-105

Levèfre, P. (2012) 'Mise en scène and Framing: Visual Storytelling in Lone Wolf and Cub', in M. Smith (ed), Critical Approaches to Comics: Theories and Methods. New York and London: Routledge, pp. 71-83

McCloud, S. (1994) Understanding Comics, New York: Harper Perennial

McCloud, S. (2000) Reinventing Comics, New York: Harper Perennial

Mitchell, W. (2014) 'Comics as Media: Afterword', Critical Inquiry, (40)3, 255-265

Munroe, R. (2005-) xkcd [online]. Available at http://xkcd.com. Accessed 18 April 2015.

Munroe, R. (2012) 'Click and Drag', in xkcd [online]. Available at http://xkcd.com/1110. Accessed 18 April 2015.

Munroe, R. (2014a) 'Lorenz', in XKCD [online]. Available at http://xkcd.com/1350. Accessed 18 April 2015.

Munroe, R. (2014b) 'Pixels', in XKCD [online]. Available at http://xkcd.com/1416. Accessed 18 April 2015.

Murray, J. (2012) Inventing the Medium: Principles of Interaction Design as a Cultural Practice. Cambridge: MIT Press

Ong, W. (1982) Orality and Literacy: The Technologizing of the Word. New York: Methuen 
Packard, S. (2009) 'Comic', in D. Lamping (ed), Handbuch der literarischen Gattungen, Stuttgart: Alfred Kröner, pp. 113-120

Paech, J. (1998) 'Intermedialität: Mediales Differenzial und transformative Figuration', in J. Helbig (ed), Intermedialität: Theorie und Praxis eines interdisziplinären Forschungsgebietes, Berlin: Schmidt, pp. 14-30

Niepold, H. and Wastlhuber, H. (2000-) The Church of Cointel [online]. Available at http://www.cointel.de. Accessed 18 April 2015.

Paech, J. and Schröter, J. (2008) Intermedialität Analog/Digital: Theorien, Methoden, Analysen, München: Fink

Page, R. (2014) 'Blogs', in M. Ryan, L. Emerson and B. Robertson (eds), Johns Hopkins Guide to Digital Media, Baltimore: Johns Hopkins University Press, pp. 42-45

Parikka, J. (2012) What is Media Archaeology?, Cambridge: Polity Press

Priego Ramirez, E. (2011) The Comic Book in the Age of Digital Reproduction. Doctoral Thesis (PhD), University College London

Radl, L. (2012): 'Chicago is My Kind of Town', Cartoon Movement [online]. Available at http://www.cartoonmovement.com/icomic/38. Accessed 18 April 2015.

Rajewsky, I. (2008) 'Intermedialität und remediation: Überlegungen zu einigen Problemfeldern der jüngeren Intermedialitätsforschung', in J. Paechand J. Schröter (eds), Intermedialität Analog/Digital. Theorien, Methoden, Analysen, München: Fink, pp. $47-60$

Rajewsky, I. (2010) 'Border Talks. The Problematic Status of Media Borders in the Current Debate about Intermediality', in L. Elleström (ed), Media Borders, Multimodality and Intermediality, Basingstoke: Palgrave Macmillan, pp. 51-68

Reichert, R. (2011) 'Die Medienästhetik der Webcomics', in B. Eder, E. Klar and R. Reichert (eds), Theorien des Comics: Ein Reader, Bielefeld: Transcript, pp. 121-141

Rippl, G. and Etter, L. (2013) 'Intermediality, Transmediality, and Graphic Narrative', in D. Stein and J. Thon (eds), From Comic Strips to Graphic Novels: Contributions to the Theory and History of Graphic Narrative, Berlin: De Gruyter, pp. 191-218

Ryan, M. (2005) 'On the Theoretical Foundations of Transmedial Narratology', in J. Meister (ed), Narratology beyond Criticism: Mediality - Disciplinarity, Berlin: De Gruyter, pp. $1-23$

Sabin, R. (2006) Comics, Comix and Graphic Novels. A History of Comic Art, London: Phaidon

Samari, W., Yamartino R. and Anvari R. (2009-) Doghouse Diaries [online]. Available at http://thedoghousediaries.com. Accessed 18 April 2015.

Scheid, T. (2005) Fotografie als Metapher. Zur Konzeption des. Fotografischen im Film. Hildesheim, Zürich and New York: Georg Olms

Schröter, J. (2004) Das Netz und die virtuelle Realität: Zur Selbstprogrammierung der Gesellschaft durch die universelle Maschine, Bielefeld: Transcript

Schröter, J. (2012) 'Four Models of Intermediality', in B. Herzogenrath (ed), Travels in Intermedia[lity]: ReBlurring the Boundaries, Hanover: University of New England Press, pp. 15-36

Sina, V. (2014) 'Die Korrelation von Comic und Film: Ein Einblick in die reziproke Entwicklungsgeschichte zweier Medien', CLOSURE: Kieler e-Journal für Comicforschung, 1, 99-121 [online]. Available at http://www.closure.unikiel.de/data/closure1/closure1_sina.pdf. Accessed 18 April 2015.

Thon, J. (2014) 'Mediality', in M. Ryan, L. Emerson and B. Robertson (eds), Johns Hopkins Guide to Digital Media, Baltimore: Johns Hopkins University Press, pp. 334-336

Thoss, J. (2014) 'Tell it Like a Game: Scott Pilgrim and Performative Media Rivalry', in M. Ryan and J. Thon (eds), Storyworlds across Media: Towards a Media-Conscious Narratology, Lincoln and London: University of Nebraska Press, pp. 211-229 
Vogler, D. (1999-2001) When I am King, [online]. Available at http://www.demian5.com/king/wiak.htm/. Accessed 18 April 2015.

Wershler, D. (2011) 'Digital Comics, Circulation, and the Importance of Being Eric Sluis', Cinema Journal, (50)3, 127-134

Wershler D., Sinervo, K. and Tien, S. (2014) 'A Network Archaeology of Unauthorized Comic Book Scans', Amodern 2: Network Archaeology, 2 [online]. Available at http://amodern.net/article/a-network-archaeology-of-unauthorized-comic-book-scans/. Accessed 18 April 2015.

Wilde, L. (2012) Der Witz der Relationen. Komische Inkongruenz und diagrammatisches Schlussfolgern im Webcomic xkcd, Stuttgart: Ibidem

Wilde, L. R. A. (2014) 'Was unterscheiden Comic-“Medien"?', CLOSURE: Kieler e-Journal für Comicforschung, 1, 25-50 [online]. Available at http://www.closure.unikiel.de/data/closure1/closure1_wilde.pdf. Accessed 18 April 2015.

Willingham, B. and Buckingham M. (2006) Fables 7: Arabian Nights (and Days), New York: DC Vertigo.

Winthrop-Young, G. (2011) Kittler and the Media, Cambridge: Polity

Wolf, W.(1999) The Musicalization of Fiction: A Study in the Theory and History of Intermediality. Amsterdam: Rodopi

Wolf, W. (2005) 'Intermediality', in D. Herman, M. Jahn and M. Ryan (eds), The Routledge Encyclopedia of Narrative Theory, London: Routledge, pp. 252-256

Wright, F. (2008) 'How Can 575 Comic Books Weigh Under an Ounce? Comic Book Collecting in the Digital Age', Journal of Electronic Publishing, (11)3 [online]. Available at http://quod.lib.umich.edu/cgi/t/text/textidx?c=jep;idno=3336451.0011.304;cc=jep;rgn=main;view=text. Accessed 18 April 2015.

Živadinović, S. (2011-) Hobo Lobo of Hamelin [online]. Available at http://hobolobo.net. Accessed 18 April 2015.

Lukas R. A. Wilde M.A. is a doctoral candidate at the Department for Media Studies at Tübingen University with a $\mathrm{PhD}$ project on the implementations and functions of Manga in informative and functional areas of contemporary Japanese society. Previously, he studied at Erlangen University and the Gakugei Daigaku of Tokyo. He is a member of the Comic Studies Board of the German Society for Media Studies (http://agcomic.wordpress.com), on the editing board of the website of the German Society of Comic Studies (www.comicgesellschaft.de), and co-organiser of the German webcomic initiative Comic Solidarity (www.comicsolidarity.de). His areas of interest include picture theory, diagrammatic reasoning, comic book theory, as well as intermedia studies.

Email: Lukas.R.A.Wilde@Gmail.com 